Article

\title{
Does Service Recovery Really Work? The Multilevel Effects of Online Service Recovery Based on Brand Perception
}

\author{
Tzu-En Lu ${ }^{1}$, Yi-Hsuan Lee ${ }^{2, *}$ and Jer-Wei Hsu ${ }^{2}$ \\ 1 Department of International Business Management, Chien Hsin University of Science and Technology, \\ Taoyuan City 320, Taiwan; blueskey@uch.edu.tw \\ 2 Department of Business Administration, National Central University, Taoyuan City 320, Taiwan; \\ sifone21@ms4.hinet.net \\ * Correspondence: yihsuanlee@mgt.ncu.edu.tw
}

Received: 19 July 2020; Accepted: 18 August 2020; Published: 27 August 2020

\begin{abstract}
This study explores how customer perception of online shopping brands plays a key role in moderating the relationship between service recovery and perceived justice. We incorporated brand equity at the organizational level and brand identity at the individual level into the relationship between online service recovery and customer-perceived justice. The findings are as follows: (a) online service recovery has a positive effect on customer-perceived justice; (b) brand equity at the organizational level has a negative influence on the relationships that courtesy and compensation have with perceived justice; (c) brand identity at the individual level has a negative influence on the relationships that courtesy and compensation have with perceived justice; and (d) hierarchical linear modeling can precisely measure the relationship between organizations and customers.
\end{abstract}

Keywords: service recovery; customer-perceived justice; brand equity; brand identity

\section{Introduction}

Online shopping is an emerging service. Judging by the characteristics of this service, zero service failure is extremely difficult to achieve during the service process [1]. To thrive and sustain amid fierce competition, service providers must make service recovery to ensure customers have a satisfactory shopping experience. In addition, customer-switching cost is low in an online shopping environment; consequently, customers will switch products or service providers if recovery quality falls short of customer expectation. Therefore, online businesses should attach more importance to service recovery compared with brick-and-mortar stores [2]. Previous studies of service recovery focused on brick-and-mortar retailing, whereas research on online-shopping service recovery is scant [3]. McColl-Kennedy and Sparks (2003) indicated that customers use perceived justice to assess the responsibilities borne by service providers [4]. Therefore, we used the perceived justice theory as the framework of this study to investigate the justice that online shoppers perceive after receiving service recovery and subsequent service recovery satisfaction.

Rowley (2004) noted the importance of online branding by stating that in an electronic trading environment, where the amount of tangible interaction is significantly reduced, e-commerce business owners must secure favorable brand perception among customers [5]. Min-Hsin Huang (2011) argued that when customers have favorable brand perception of a business, the perception will serve as the basis of customer evaluation concerning the performance of future service recovery and will play a vital role in the service recovery that businesses make [6]. In previous studies on service recovery, the majority of scholars adopted the perspective of perceived justice to explore consumer evaluation of service recovery. Nevertheless, most of these studies focused on the positive and negative emotions of 
consumers triggered by perceived justice or the results of the interaction between service failure and various types of compensation, and few scholars have adopted the perspective of brands to explore the relationship between service recovery and perceived justice [7-11].

Based on the expectancy-disconfirmation theory [12], we anticipate that customers have relatively higher expectation of the service quality of strong brands. Consequently, strong brands must maintain a level of service that matches the brand status. Otherwise, customers are likely to feel a gap between actual service performance and the quality they expect and subsequently perceive unjust treatment. Hence, customer-brand perception plays a vital role in the relationship between business service performance and customer-perceived justice. To resolve problems with business service and to fill the gap in previous research, this study incorporates brand equity and brand identity, two vital factors influencing customer-brand perception, to explore the process from service recovery to perceived justice.

A brand can be defined as a name, term, sign, symbol, design, or combination of them which is intended to identify the goods and services of one seller or group of sellers and to differentiate them from those of competitors [13]. The term brand equity was first used widely by US advertising practitioners in the early 1980s [14]. Brand equity is a vital concept in marketing, management and branding studies [15]. However, in a business environment where the Internet is used as the media, the characteristics of the Internet are unique brand capital. In addition, brand power also differs. Therefore, brand equity should be reviewed in the context of an online environment [16]. Kim, Sharma, and Setzekorn (2002) argued that introducing the concept of brand equity is beneficial for e-commerce business owners to build strong Internet brands [17]. Laudon, Traver, and Elizondo (2007) stated that brand equity symbolizes the image and service quality of online shopping sites, attracting consumers to trust the brands of online shopping sites [18]. They confirmed that brands are still the element used to segment and emphasize the products and services of businesses in online shopping.

Brand equity derives from the positive associations that consumers have of a brand based on previous experience and current memory $[19,20]$. According to the expectancy-disconfirmation theory, when the service recovery made by a firm with high brand equity fails to meet the high expectations held by customers, their level of satisfaction is the gap between expected perception and brand performance. Because the firm has high brand equity, consumers are even more disappointed; this feeling has a stronger negative effect on customer-perceived justice. Numerous studies have examined the relationship between brand equity and consumer products or services [21-25] or investigated brand management [26-28]. However, there are few scholars have explored how brand equity moderates the effects of online service recovery on customer-perceived justice. Therefore, this study adopted the perspective of brand equity to analyze the effects of service recovery on customer-perceived justice.

Individual perception of online brands is an unelectable influencing factor when firms make service recovery. Brand identity is important because it allows consumers to show their uniqueness and status [29]. A strong customer-brand identity indicates that the concept represented by a brand is consistent with the self-concept of consumers [30]. Lam, Ahearne, Hu, and Schillewaert (2010) found that brand identity influences customer purchase behavior and service satisfaction related to a brand [31]. Furthermore, negative word of mouth can easily reach individuals via social groups because of the instantaneity of social media in the online environment. Therefore, online businesses, in particular, should secure customer-brand identity [9,32]. Customers with a strong brand identity have relatively in-depth brand knowledge of the firm as well as a strong connection with and high expectation of the brand [32]. Consumer perception of service recovery is influenced by their perception of the brand [6]. According to the expectancy-disconfirmation theory, customers with a strong brand identity tend to have high service expectations when service failure occurs in a firm. Consequently, a drop in firm performance can easily jeopardize customer-perceived justice. Therefore, this study examines how brand identity moderates the relationship between service recovery and perceived justice. Previous research on the influence of brand equity on the relationship between service recovery and perceived justice has overlooked differences between individuals and a brand at the overall 
level [33-35]. Considering this, we employed hierarchical linear modeling (HLM) [36] to develop the research framework of this study, the purpose being to precisely measure the relationship between organizations and customers.

This study presents the following key contributions. (a) We used the perceived justice theory to measure customer perception of service recovery and subsequent service recovery satisfaction. Although numerous scholars have employed this framework in previous studies [33-35], few studies have adopted the perspective of individual brand perception to measure the influence of service recovery on customers. Therefore, this study incorporated brand identity, a factor at the individual level, to examine how online brand identity moderates the relationship between service recovery and perceived justice. (b) Although scholars have studied whether business brand equity affects the relationship between service recovery and service recovery satisfaction [6], few studies have explored whether brand equity affects the relationship between service recovery and perceived justice. This study incorporated brand equity to explore the moderating effect of this factor and used brand equity as a variable at the organizational level to investigate whether brand equity has a cross-level moderating effect and whether the individual level moderates the relationship between service recovery and perceived justice. (c) Finally, we adopted an HLM as the method of this study, performing precise evaluations of variables at differing levels. Brand perception was divided into two levels: brand equity at the organizational level and brand identity at the individual level. Previous studies focused on the relationships among variables at a single level. By contrast, we introduced a moderating mechanism to examine cross-level relationships: (1) a moderating model at the individual level: brand identity affects the relationship between service recovery and customer-perceived justice; (2) a moderating model at the organizational level: brand equity affects the relationship between service recovery and customer-perceived justice.

\section{Literature Review and Hypotheses}

\subsection{Service Failure}

Service failure was defined as customer dissatisfaction with business service (real and perceived) or the process of service delivery [37]. Keaveney (1995) found service failure increases customer swtiching intentions while reducing brand loyalty and customer satisfaction with a firm [38]. Barwise, Elberse, and Hammond (2002) argued that although the Internet has not altered the principles of marketing, failures that occur in the online environment differ substantially from those that occur in conventional brick-and-mortar environments. Examples of online service failures involve credit card safety, website browsing experience, and personal privacy [39]. Furthermore, because customers shopping at online stores cannot examine actual products prior to purchase, customers are more likely to feel a significant gap between their expectations and the purchased products or services.

Kuo, Yen, and Chen (2011) studied the types of online shopping failures and divided online service failures into three dimensions and 18 sub-dimensions, ranking the failures based on the number of occurrences reported by customers [40]. The scholars adopted a customer perspective to collect and categorize failures that firms committed while providing online shopping services. The focus was similar to the topic of this study. In addition, the findings of Kuo, Yen, and Chen (2011) were more comprehensive compared with the types of failures identified by previous scholars $[2,40,41]$. Therefore, we adopted the dimensions identified in the Kuo, Yen, and Chen (2011) study and invited the participants to select the types of service failures they encountered [40].

\subsection{Service Recovery}

Service recovery is the actions an organization takes in response to service failure [42]. Bitner (1990) argued that service recovery has significant influence on customer evaluations. Compared with first-time or daily purchases, customers are more likely to behave emotionally and pay attention to details during service recovery [43]; additionally, customers often feel more dissatisfied with the 
outcomes of service recovery than with the initial service failure. Successful service recovery enables firms to resolve customer complaints, rectify customer dissatisfaction, and build up customer trust in a firm [44]. Hoffman, Kelley, and Chung (2003) divided service recovery into the following three dimensions: (1) compensation (using discounts or coupons to compensate customers for the service failure a firm has caused), (2) efficient recovery (compensating for service failure by making speedy responses), and (3) psychological compensation (using apology and courtesy as means to compensate for service failure) [45].

Today, the Internet environment presents problems that do not exist in a brick-and-mortar environment such as website system fluency, the privacy and security during transaction processes, delivery, and customer-service system support. Although service failures in this context do not result in tangible customer losses, customers might feel inconvenienced and lose trust in the websites. Apology, speed of response, and courtesy, which are three types of psychological compensation made to customers, are vital in an online environment compared with a brick-and-mortar environment. In addition, customers also value the delivery speed and packaging condition of a firm, which determine economic gains and losses. In this situation, compensation is a more effective means of service recovery $[46,47]$. In summary, we classify online service recovery into the following four dimensions: apology, speed of response, courtesy, and compensation.

\subsection{Perceived Justice}

The perceived justice theory was developed based on the social exchange theory and the justice theory [48]. Konovsky (2000) stated that perceived justice is a necessary factor when examining individuals in the context of service conflicts. Service failure is a typical type of service conflict and service recovery is a means to compensate for service failure [49]. Therefore, the perceived justice theory can be used to adequately evaluate the outcome of service recovery. In other words, customer-perceived justice is a key factor in judging the outcome of service recovery [50]. Numerous studies have indicated that the recovery strategies a firm adopts can be evaluated using the three elements of the perceived justice theory, which are distributive, procedural, and interactional justice [7,51-53].

Research has shown that apology is closely connected with customer-interactional justice. Apology is a way of handling customer relations and using communication to compensate for the psychological loss in customers during service recovery. A timely and appropriate apology has a positive effect on the interactional justice in customer relations [54]. Compensation has a strong tie with distributive justice because compensation is related to the cost-benefit allocation of a firm. In addition, compensation represents the actual gain a customer receives when a firm makes service recovery. When the compensation a firm provides meets the expectation of a customer, distributive justice is affected significantly in a positive way [55]. Speed of response and procedural justice are closely related. Speed of response affects customer perception of the justice of firm policies and how a firm handles customer problems [56,57]. A lower speed of response leads to a lower level of customer-perceived procedural justice [33]. The relationship between courtesy and interactional justice is also crucial. Courtesy refers to the contents of and feelings in customer interaction during service recovery. When service personnel show respect and a soft attitude, interactional justice is affected significantly in a positive way [51]. Furthermore, Mostafa, R. Lages, and Sääksjärvi (2014) also found that the recovery measures mentioned in this paragraph have significant positive effects on overall customer-perceived justice [58]. Therefore, previous studies have shown various recovery strategies have differing effects on perceived justice [59]. Numerous scholars have combined the three dimensions of justice in their studies [34,60]. Hence, we combined the three dimensions to form a single dimension, namely, perceived justice. Based on detailed explanations of perceived justice as a concept, we developed the following four hypotheses using four specific recovery strategies adopted to affect perceived justice:

Hypothesis 1 (H1). Apology affects perceived justice positively; 
Hypothesis 2 (H2). Compensation affects perceived justice positively;

Hypothesis 3 (H3). Speed of response affects perceived justice positively;

Hypothesis 4 (H4). Courtesy affects perceived justice positively.

\subsection{Expectancy Disconfirmation Theory}

Oliver (1980) stated that satisfaction can be examined using one of the following two constructs: performance-specific expectation and expectancy-disconfirmation [61]. Specifically, confirmation occurs when product performance matches expectation. Negative disconfirmation occurs when a product performs worse than expected, and positive confirmation occurs when a product performs better than expected. Oliver and DeSarbo (1988) developed the expectancy-disconfirmation model, arguing that satisfaction and dissatisfaction are results of a comparison between pre-purchase expectation and actual purchase outcomes [62]. Consumers often make subjective evaluations of products, and product performance is an objective evaluation criterion. The evaluations consumers make regarding actual and expected performance can yield one of the following three outcomes: (1) positive disconfirmation: performance is better than expected, and consumers are satisfied; (2) simple confirmation: performance matches expectation; (3) negative disconfirmation: performance is worse than expected, and consumers are dissatisfied. Previous studies on satisfaction have shown that expectancy-disconfirmation affects satisfaction and perceived quality. Numerous scholars have indicated that expectancy-disconfirmation affects customer satisfaction $[12,63,64]$. Some scholars have also argued that expectancy-disconfirmation affects perceived quality $[55,65]$. Therefore, the expectancy-disconfirmation theory is a vital criterion measuring customer satisfaction and perception.

\subsection{Brand Equity}

Aaker (2009) defined brand equity as the added value of a brand in addition to the original value of a product or service [66]. Brand equity entails the assets and liabilities of a brand, as well as five other components, namely, brand loyalty, name awareness, perceived quality, brand associations, and other proprietary assets (e.g., patent and trademark).

Considering the characteristics of the Internet, building a brand has significant influence on a firm [67]. On the Internet, the overall corporate image of a firm can be accessed only via a computer screen, and customers cannot touch or feel the actual products. Consequently, brand equity is a sensitive and vital factor for customers [68]. Furthermore, the Internet is a dynamic environment, where consumers can form social groups to communicate their experience with and thoughts of a brand. Therefore, the influence of word of mouth and user recommendation should not be overlooked [69]. Online service recovery satisfaction has a positive effect on word of mouth and recommendation; therefore, successful online service recovery is a key factor influencing online brand equity in a positive way [6].

Wallin Andreassen (2000) found that during the process of service recovery, the interaction between service providers and customers significantly affects customer perception of the recovery [70]. The characteristics of service are intangibility, heterogeneity, and inseparability [23]; therefore, the brand of a service plays the vital role of a relationship builder, affecting the process where service providers deliver brand value to customers. Zeithaml (1988) indicated service quality is an element of brand value and high brand equity results in higher customer expectation of service quality [24]. Klaus and Maklan (2007) stated that when a brand can successfully manage the service experience of customers, the firm becomes extremely competitive and can distinguish itself from its competitors [69]. Simultaneously, the brand is a window for customers to understand the content of the service provided by a firm. Yoo and Donthu (2001) also argued that service quality has a strong effect on brand value [25]. In other words, brand and service are closely connected. However, strong brands can sometimes pose hidden threats. Brady, Cronin Jr, Fox, and Roehm (2008) found because customers tend to have high 
expectations of strong brands, customers are more disappointed when the brands fail [71]. Apology is important for handling customer relations and for using communication to compensate for the psychological loss in customers during service recovery. Timely and appropriate apology has a positive effect on the interactional justice in customer relations. Nevertheless, customers often have high expectations of the perceived quality and name awareness of firms with high brand equity. Based on the expectancy-disconfirmation theory, Oliver (1997) found customers have high expectations of brands with a positive image [72]. Consequently, customers feel shocked and betrayed when the brand fails to deliver the oral psycholocial compensation customers expect. These negative emotions undermine the effects of service recovery, further resulting in stronger customer dissatisfaction. Ultimately, customers perceive weaker interactional justice. By contrast, customers have low expectations of firms with low brand equity. Hence, customers feel responded to and empathized with in an unexpected way when these firms apologize. Consequently, customers perceive stronger interactional justice. Therefore, we hypothesize the following.

Hypothesis 5 (H5). Brand equity has a negative moderating effect on the influence of apology on perceived justice.

Compensation, which is related to the cost-benefit allocation of a firm, represents the actual gain customers receive in the service recovery made by a firm. Compensation that meets customer expectation has a positive effect on customer-perceived distributive justice. Brady et al. (2008) found that customers have high expectations of brands with high brand equity and that the compensation firms provide (in the forms of cash or discount) must match the image and self-defined standards of a firm. By contrast, customers have low expectation of firms with low brand equity. When these firms provide compensations that exceed customer expectation, customers are often surprised and feel rewarded and compensated. Consequently, customer satisfaction and customer-perceived distributive justice is higher. Therefore, we hypothesize the following.

Hypothesis 6 (H6). Brand equity has a negative moderating effect on the influence of compensation on perceived justice.

Speed of response affects customer perception of the justice of firm policies and how a firm handles customer problems. When service providers respond to customer questions instantly, customer-perceived procedural justice is high. However, customers expect firms with high brand equity to have high perceived quality and name awareness. Based on the expectancy-disconfirmation theory, Oliver (1997) argued that customers expect brands with a positive image to have comprehensive employee training, a control mechanism, and a service delivery system to facilitate optimal service recovery $[72,73]$. Therefore, when firms with high equity fail to immediately respond to customer expectation at this stage, customers feel exceedingly dissatisfied with the brand; consequently, customer-perceived procedural justice is reduced. By contrast, customers have a low expectation of firms with low brand equity. Therefore, when these firms make speedy responses to customer requests, customers are surprised and feel respected; consequently, customer-perceived procedural justice is high. Hence, we hypothesize the following.

Hypothesis 7 (H7). Brand equity has a negative moderating effect on the influence of speed of response on perceived justice.

Courtesy refers to the contents of and feelings in customer interaction during service recovery. When service personnel show respect for customers, interactional justice is affected significantly in a positive way. However, when consumers perceive high brand equity in a firm, the firm is differentiated from other brands and consumers have stronger reasons to purchase products from the brand and hold a positive perception of the brand. Based on the expectancy-disconfirmation theory, Oliver (1997) indicated that customers have high positive expectations of the quality, reliability, 
and trustworthiness of firms that have high brand equity [72,74]. Courtesy is a key factor involving customer trust and customer-perceived reliability. Customers feel increasingly dissatisfied when the attitude of service personnel is worse than expected and the service details are unsatisfactory. Consequently, customer-perceived interactional justice is low. By contrast, customers have low expectation of firms with low brand equity. Therefore, when staff of these firms interact with customers courteously, customers are surprised, feel respected, and perceived the staff as friendly. Consequently, customer-perceived interactional justice is high. Hence, we hypothesize the following.

Hypothesis 8 (H8). Brand equity has a negative moderating effect on the influence of courtesy on perceived justice.

\subsection{Brand Identity}

Brand identity was defined as how a brand can effectively and powerfully convey its message on the market; it implies that consumers perceive a brand as unique and connect the uniqueness with their own image and status, thereby developing identification with the brand $[31,75,76]$. McEwen (2005) argued that consumers tend to build a strong relationship with brands because customers use consumption as a way to achieve self-affirmation, identification with others, and social identity. In addition, brands can convey and enhance the distinctiveness of these people [32].

The rapid development of online communities in recent years allows consumers to instantly communicate product and service information regarding a brand [69]. Online communities can easily affect the brand identity of a person. When customers have a negative perception of the products or service of a brand, negative word of mouth can instantly spread across the communities because of the instantaneity of social media. Consequently, brand identity and brand loyalty are undermined [9,32].

When customers have a strong brand identity, they have in-depth brand knowledge of the firm, perceive an intimate connection with the brand, and have high expectations [32]. Lam et al. (2010) indicated that brand identity affects the relationship that brand behavior has with brand switching intentions and customer satisfaction [31]. Therefore, brand identity has a strong influence on customer relations, and customers with a strong brand identity believe that the brand is unique to them. According to the expectancy-disconfirmation theory, when customers are in contact with firms they strongly identify with, customers expect the firms to treat what the customers consider vital to be the focus of their service. Consequently, when service failure occurs, customers find it unbelievable or even overemphasize the failure. No amount of oral psychological compensation a firm makes can improve customer interaction. By contrast, when firms that customers have a weak brand identity with, and hence low expectations of, apologize sincerely, customers are surprised, and customer-perceived interactional justice is enhanced. Therefore, we hypothesize:

Hypothesis 9 (H9). Brand identity has a negative moderating effect on the influence of apology on perceived justice.

Appropriate compensation in various forms (e.g., discount, refund, or coupon) can satisfy customers, who subsequently perceive firm policies and earnings distribution as reasonable. When brand identity is strong, consumers receive numerous brand messages and project their self-image to the brand image, holding an ideal image of the brand. When service failure occurs, customers expect service providers to respond in the idealized way they anticipate the firm, taking for granted the unrealistically high standards they set and requesting unexpected compensations. Consequently, these customers have relatively weak perception of financial justice. Nevertheless, when brand identity is weak, consumers tend to view the brand as an entity outside of themselves, showing low expectation of the service recovery performance of the brand. Therefore, when the brand makes recovery of any kind, consumers have weak perception of injustice. We hypothesize the following. 
Hypothesis 10 (H10). Brand identity has a negative moderating effect on the influence of compensation on perceived justice.

The speed of response affects the speed of the overall operation and service procedure of a firm and is closely related to firm policies and the attitude of service personnel. When service providers respond to customer complaints instantly, customers believe the firm has a smooth service system, thereby developing favorable perceived procedural justice. However, customers with a strong brand identity have high expectations of the firm, expecting the firm to respond to themselves as unique individuals and provide responses other than standard service system replies [77]. Consequently, customer-perceived procedural justice is at a low level. By contrast, customers with a weak brand identity do not expect a high service standard. Therefore, when the firm provides instant feedback, customers are pleasantly surprised with the service and perceive higher procedural justice. Hence, we hypothesize the following.

Hypothesis 11 (H11). Brand identity has a negative moderating effect on the influence of speed of response on perceived justice.

Courtesy influences customer-perceived justice positively. According to the expectancydisconfirmation theory, customers have high expectations of brands they highly identify with and expect the firms to provide high value and a unique experience. During the interaction with service providers, customers compare the present experience with that of previous consumption and emotional responses [78]. When service personnel react in an unsuitable emotion or behave less courteously than before, customers with a strong brand identity tend to feel dissatisfied, thereby showing weaker perception of interactional justice. By contrast, customers have low expectations of firms they have a weak identity with. Therefore, when these firms provide respectful and courteous service, customers tend to accept the exchange of brand information and the way of outcome communication, thereby developing a higher level of perceived interactional justice. Hence, we hypothesize the following.

Hypothesis 12 (H12). Brand identity has a negative moderating effect on the influence of courtesy on perceived justice.

\subsection{Service Recovery Satisfaction}

Service recovery satisfaction was defined as customer satisfaction with service failure handling [79]. Orsingher, Valentini, and de Angelis (2010) argued that service recovery satisfaction is the customer assessment of how a firm resolves issues [80].

Switching cost is low on the Internet. Firms that respond to customers can instantly prevent customers from feeling unjust, and can thus distinguish the firms from their competitors [81]. James G. Maxham III and Netemeyer (2003) conducted a study on online shopping service failure and found that distributive and procedural justice affect service recovery satisfaction positively [9]. Mattila and Patterson (2004) also indicated high customer-perceived distributive and interactional justice enhance service recovery satisfaction [10]. Del Río-Lanza et al. (2009) stated that distributive, procedural, and interactional justice all affect service recovery satisfaction positively [7]. This finding is consistent with those of Baron, Harris, Elliott, Mattila, and Cranage (2005) and Hocutt et al. (2006) [8,41]. Tax et al. (1998) showed the interactions of distributive, procedural, and interactional justice also affect service recovery satisfaction positively [55]. Therefore, we hypothesize the following.

Hypothesis 13 (H13). Perceived justice affects service recovery satisfaction positively. 


\section{Research Methodology}

\subsection{Research Framework}

This study is based on service recovery (apology, compensation, speed of response, and courtesy) and perceived justice theories. Figure 1 shows the research model. All the antecedents were examined through customer-perceived justice before influencing service recovery satisfaction. This study investigated how brand equity and brand identity moderating online services recovery affect customer-perceived justice.

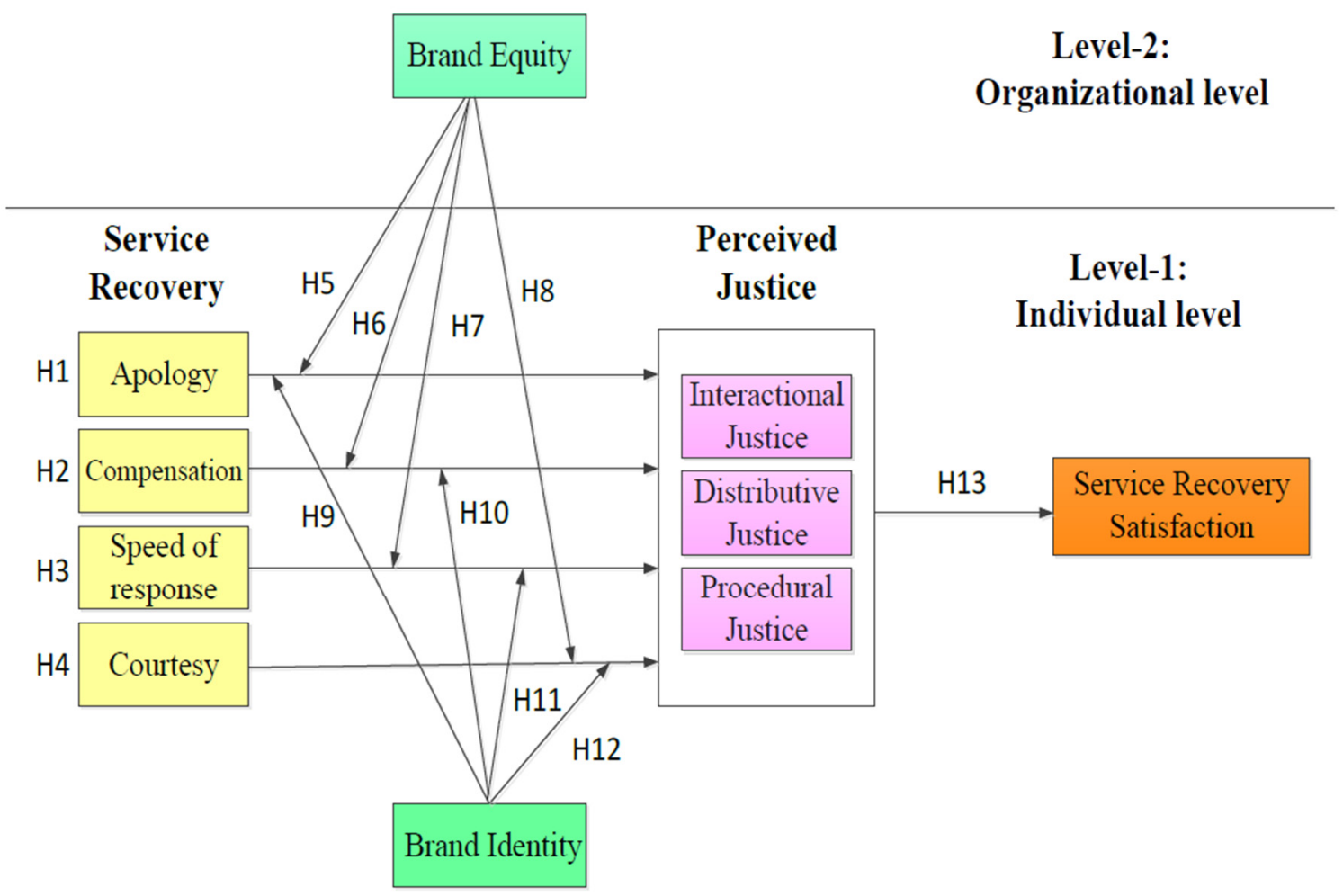

Figure 1. Research framework.

\subsection{Data Collection and Sampling}

In this study, a survey was conducted upon convenience sampling. Questionnaires were distributed online and at physical locations. A total of 478 questionnaires were distributed, and 353 samples were retrieved, including 193 online questionnaires and 160 written questionnaires, for a valid return rate of $74 \%$. These selected online brands from among the Top 100 most popular online brands of 2018 in Taiwan for the survey. Each online brand's customer data was grouped into one team, with a total of 32 teams. Each team consisted of an average of 11 people (ranging from 9 to 17), a total of 353 samples. Among the 353 respondents, most of them were women (227, or 65.0\%), 21-30 years old $(54.4 \%)$, the majority had an undergraduate degree (58.4\%), most common were students $(56.1 \%)$, had an average monthly income of NTD 10,000 or less (45.3\%), and were unmarried (43.6\%).

\subsection{Measures}

The measurement was based on a Likert5-point scale, ranging from 1 (strongly disagree) to 5 (strongly agree).

\subsubsection{Service Recovery}

The scale for service recovery included 17 items, which were modified from Mostafa et al. (2014) [58]. It contains four dimensions: apology, compensation, speed of response, and courtesy. 
Sample items by dimension included (a) Apology: "The company apologized to me for what had happened" (4-items); (b) Compensation: "The compensation the company gave me for the loss incurred is good" (5-items); (c) Speed of response: "The company reacted promptly to my inquiries" (4-items); and (d) Courtesy: "The service provider was friendly to me" (4-items). The participants' responses to the items of each dimension were averaged into a composite score; a higher score indicates greater service recovery (apology, compensation, speed of response, and courtesy) (see Table A1 in Appendix A).

\subsubsection{Perceived Justice}

The scale for perceived justice included 17 items, which were modified from del Río-Lanza et al. (2009) (see Table A1) [7]. It consists of three dimensions: distributive justice, procedural justice, and interactional justice. Sample items by dimension included (a) Distributive justice: "Considering the trouble caused and the time lost, the compensation I received from this shopping website was acceptable" (5-items); (b) Procedural justice: "I think my problem was resolved in the right way" (5-items); and (c) interactional justice: "The employees in this shopping website showed interest in my problem" (7-items). The participants' responses to the items of each dimension were averaged to form an overall perceived justice score based on existing research perspectives (e.g., Sun and He, 2014; Varela et al., 2015) $[34,60]$. In this study, the correlations among the three dimensions ranged from 0.655 to 0.691 . Second-order confirmatory factor analysis (CFA) was then conducted to determine whether the three dimensions were nested under a second-order factor (i.e., overall score of perceived justice). The CFA results indicated that the second order model fit the data well (CFI $=0.927, \mathrm{NFI}=0.920$, $\mathrm{GFI}=0.910, \mathrm{AGFI}=0.855, \mathrm{RMSEA}=0.066$, and $\mathrm{RMR}=0.033$ ). The result suggested that it is appropriate to combine the scores of the three dimensions into an overall score of perceived justice.

\subsubsection{Brand Equity}

The scale for brand equity included 13 items, which were modified from Pappu et al. (2005) and Netemeyer et al. (2004) (see Table A1) [82,83]. The scale is consisted of three dimensions: perceived quality, brand association, and brand image. Sample items by dimension included (a) Perceived quality: "X offers good quality services" (4-items); (b) Brand association: "I trust the company that owns the brand X" (5-items); and (c) Brand image: "I think X has a strong image" (4-items). The participants' responses to the items of each dimension were averaged to form an overall brand equity score based on existing research perspectives. In this study, the correlations among the three dimensions ranged from 0.637 to 0.645 . Second-order confirmatory factor analysis (CFA) was conducted to determine whether the three dimensions were nested under a second-order factor (i.e., overall score of brand equity). The CFA results showed that the second-order model fit the data well (CFI $=0.873, \mathrm{NFI}=0.931$, $\mathrm{GFI}=0.904$, AGFI $=0.757$, RMSEA $=0.069$, and $\mathrm{RMR}=0.041$ ). The result suggested that it is appropriate to combine the scores of the three dimensions into an overall score of brand equity.

\subsubsection{Brand Identity}

The scale for brand identity included four items, which were modified from Bhattacharya and Sen (2003) (see Table A1) [84]. The respondents were asked to indicate the extent of their feelings about their brand identity. Sample items included: " $X$ has a distinctive identity" and " $X$ stands out from its competitors". These items were averaged into a composite score with higher scores indicating greater brand identity.

\subsubsection{Service Recovery Satisfaction}

The scale for service recovery satisfaction included three items, which were modified from Smith et al. (1999) [33]. The respondents were asked to indicate the extent of their feelings about their service recovery satisfaction. Sample items included: "Overall I was satisfied with the way the complaint was 
handled" and "Overall I got what I wanted." These items were averaged into a composite score with higher scores indicating greater service recovery satisfaction.

\subsection{Control Variables}

Prior studies have suggested that descriptive control variables such as customer gender, age, race, income, education, and marital status influence service recovery satisfaction [85]. Wu et al. (2014) argued that demographic variables such as gender, age, education, and occupation impact service recovery satisfaction [11]. Thus, in order to enhance the generalizability of the results, this study controlled participants' gender, age, income, education, occupation, and marital status when testing individual-level hypotheses.

\subsection{Common Method Variance}

As data collection in this study may involve errors associated with common method variance (CMV), procedural remedies and statistical remedies were adopted according to Podsakoff, MacKenzie, Lee and Podsakoff (2003) [86]. First, the researchers presented the respondents with detailed information about the precautions taken to ensure their anonymity to decrease social desirability bias. The respondents were also assured that there were no right or wrong answers to the survey questions, in order to alleviate evaluation apprehension. Moreover, Harman's one-factor test was used [86]. The principal component factor analysis was conducted by entering all the scales used in this study to determine whether a single general factor accounted for a majority of the variance among all the scales. The results of factor analysis indicated that ten factors with eigenvalues greater than one explained $57.32 \%$ of the total variance. The first factor accounted for $38.60 \%$ (less than $50 \%$ ) of the variance, which did not explain most of the variance [87]. The above-mentioned procedural and statistical remedy ensured that the common method bias was not a major concern in the present study.

\section{Analysis and Results}

\subsection{Preliminary Analysis}

Table 1 shows that the reliability of the questionnaire items ranged from 0.711 to 0.907 , exceeding the acceptable value of 0.50 [88]. All of the composite reliabilities (CR) exceeded the threshold value of 0.6 ( 0.713 to 0.922 ). The AVEs of Apology and Perceived justice were slightly below the criterion of 0.5 . However, according to Jiang, Klein, and Carr (2002), when the AVE estimate is less than 0.5 but the dimension CR is above 0.6, there is convergence validity (see Table 1) [89]. The model-fit measures were used to assess the model's overall goodness of fit (GFI, AGFI, NNFI, RMR) and the values of GFI AGFI, NFI and RMR all exceeded their respective common acceptance levels [90]. Overall, the scale items of the eight variables had good convergent validity (see Table 1).

Table 1. Convergent validity.

\begin{tabular}{ccccccccc}
\hline Variable & $\alpha$ & $\boldsymbol{\lambda}$ & AVE $>\mathbf{0 . 5}$ & $\mathbf{C R}>\mathbf{0 . 6}$ & GFI $>\mathbf{0 . 9}$ & AGFI $>\mathbf{0 . 9}$ & NFI $>\mathbf{0 . 9}$ & RMR $<\mathbf{0 . 0 8}$ \\
\hline Apology & 0.78 & $0.617 \sim 0.757$ & 0.475 & 0.782 & 0.996 & 0.98 & 0.997 & 0.014 \\
Compensation & 0.82 & $0.625 \sim 0.870$ & 0.61 & 0.885 & 0.994 & 0.983 & 0.99 \\
Speed of response & 0.71 & $0.569 \sim 0.897$ & 0.554 & 0.829 & 0.995 & 0.977 & 0.977 \\
Courtesy & 0.757 & $0.621 \sim 0.789$ & 0.52 & 0.811 & 0.994 & 0.969 & 0.969 & 0.016 \\
Perceived justice & 0.907 & $0.546 \sim 0.829$ & 0.613 & 0.938 & 0.946 & 0.927 & 0.927 \\
Brand equity & 0.889 & $0.457 \sim 0.868$ & 0.585 & 0.959 & 0.929 & 0.906 & 0.906 & 0.017 \\
Brand identity & 0.711 & $0.553 \sim 0.834$ & 0.54 & 0.821 & 0.999 & 0.997 & 0.997 \\
Service recovery & 0.802 & $0.715 \sim 0.829$ & 0.607 & 0.822 & 0.998 & 0.998 & 0.991 \\
satisfaction & & & & & & & 0.004 & 0.015 \\
\hline
\end{tabular}

Note: $\alpha=$ Cronbach's alpha. 
The means, standard deviations and correlations for the study variables are presented in Table 2, showing that all the measurement variables were positively and significantly correlated with each other $(p<0.001)$. Discriminant validity was assessed by comparing the shared variance between the factors with the AVEs for the eight factors [91]. Table 2 shows that the constructs all met this criterion. Hence, discriminant validity was assured. To sum up, the eight constructs reached satisfactory levels of reliability, convergent validity, and discriminant validity.

Table 2. Means, standard deviations, correlations, and discriminant validity.

\begin{tabular}{cccccccccc}
\hline & & $\mathbf{1}$ & $\mathbf{2}$ & $\mathbf{3}$ & $\mathbf{4}$ & $\mathbf{5}$ & $\mathbf{6}$ & $\mathbf{7}$ & $\mathbf{8}$ \\
\hline 1 & Apology & $0.689^{\mathrm{a}}$ & & & & & & & \\
2 & Compensation & $0.505^{* * *}$ & $0.781^{\mathrm{a}}$ & & & & & & \\
3 & Speed of response & $0.547^{* * *}$ & $0.536^{* * *}$ & $0.744^{\mathrm{a}}$ & & & & & \\
4 & Courtesy & $0.468^{* * *}$ & $0.450^{* * *}$ & $0.549^{* * *}$ & $0.721^{\mathrm{a}}$ & & & & \\
5 & Perceived justice & $0.608^{* * *}$ & $0.687^{* * *}$ & $0.698^{* * *}$ & $0.659^{* * *}$ & $0.783^{\mathrm{a}}$ & & & \\
6 & Brand identity & $0.431^{* * *}$ & $0.455^{* * *}$ & $0.424^{* * *}$ & $0.454^{* * *}$ & $0.539^{* * *}$ & $0.764^{\mathrm{a}}$ & & \\
7 & Brand equity & $0.506^{* * *}$ & $0.606^{* * *}$ & $0.565^{* * *}$ & $0.586^{* * *}$ & $0.710^{* * *}$ & $0.721^{* * *}$ & $0.735^{\mathrm{a}}$ & \\
8 & Service recovery & $0.515^{* * *}$ & $0.580^{* * *}$ & $0.534^{* * *}$ & $0.555^{* * *}$ & $0.772^{* * *}$ & $0.473^{* * *}$ & $0.599^{* * *}$ & $0.779^{\mathrm{a}}$ \\
& satisfaction & & & & & & & & \\
& Mean & $3.719^{*}$ & 3.622 & 3.656 & 3.791 & 3.754 & 3.704 & 3.685 & 3.802 \\
& SD & $0.744^{*}$ & 0.73 & 0.631 & 0.631 & 0.571 & 0.53 & 0.622 & 0.755 \\
\hline
\end{tabular}

Note: ${ }^{* * *} p<0.001$; ${ }^{a}$ The diagonal shows the square roots of AVE, and the other matrix entries are the factor correlations.

\subsection{Aggregation Testing}

To investigate the group-level properties of the measurement in this study and the appropriateness of the data aggregation, this study tested inter-rater agreement by computing the rwg values of group-level brand equity [92]. The results showed that the large value for group-level brand equity was 0.969 . The rwg values exceeded the acceptable level of 0.7 . Furthermore, this study calculated intraclass correlation (ICC (1)) and reliability of group means (ICC (2)) for group-level brand equity [36]. The (ICC (1)) value for brand equity was 0.123 , which is above the acceptable level reported in the literature [93]. Finally, the value of ICC (2) was 0.631. As shown in the results, the ICC (2) value for brand equity was slightly below the accepted value of 0.70 suggested by Glick (1985) [94]. However, according to Chen and Bliese (2002), aggregation should be justified by theory and supported by high rwg and significant between group variance [95]. Besides, LeBreton and Senter (2008) suggested that the justification of aggregation in only relying on ICC (2) could cause highly erroneous decisions [96]. Thus, aggregating the responses of brand equity into the group-level was carried out.

\subsection{Hierarchical Linear Model Analysis}

\subsubsection{Perceived Justice and Service Recovery Satisfaction of Null Model}

To examine the appropriateness of multilevel analysis, this study estimated a null model in which no predictors were specified at either Level 1 (Individual level) or Level 2 (organizational level) to test the significance level of the Level 2 residual variance in the intercept. The results showed significant between-group variance $\left(\chi^{2}=58.064, d f=31, p<0.01\right)$ for perceived justice. Calculating the ICC value indicated that $22 \%$ of the variance in perceived justice was at Level 2 . The results showed significant between-group variance $\left(\chi^{2}=54.684, d f=31, p<0.01\right)$ for service recovery satisfaction. The calculated ICC value indicated that $20.9 \%$ of the variance in service recovery satisfaction was at Level 2 . Thus, a multilevel analysis was justified.

\subsubsection{Tests of Hypotheses}

The results of M1 M4 showed that service recovery: apology, compensation, speed of response, and courtesy $\left(\gamma_{70}=0.076, p<0.05, \gamma_{80}=0.221, p<0.001, \gamma_{90}=0.205, p<0.001\right.$, and $\gamma_{100}=0.219$, 
$p<0.001$ ) were significantly associated with perceived justice. Hence, service recovery-apology, compensation, speed of response, and courtesy-has a positive effect on perceived justice. Thus, H1 H4 were supported. The results of M13 showed that perceived justice $\left(\gamma_{70}=0.925, p<0.001\right)$ was significantly associated with service recovery satisfaction. Hence, perceived justice has a positive effect on service recovery satisfaction. Thus, $\mathrm{H} 13$ was supported. The results of hypothesis testing are listed in Table 3.

Table 3. The hierarchical linear modelling (HLM) results of service recovery, perceived justice and service recovery satisfaction.

\begin{tabular}{|c|c|c|c|c|c|c|c|}
\hline \multirow[b]{2}{*}{ Dependent Variable } & \multicolumn{3}{|c|}{ Perceived Justice } & \multicolumn{4}{|c|}{ Service Recovery Satisfaction } \\
\hline & $\begin{array}{l}\text { Null } \\
\text { Model }\end{array}$ & M1 & M2 & M3 & M4 & $\begin{array}{c}\text { Null } \\
\text { Model }\end{array}$ & M13 \\
\hline Intercept $\left(\gamma_{00}\right)$ & $3.752 * * *$ & $3.722 * * *$ & $3.722 * * *$ & $3.722 * * *$ & $3.722 * * *$ & $3.800 * * *$ & $3.745^{* * *}$ \\
\hline Gender $\left(\gamma_{10}\right)$ & & 0.055 & 0.055 & 0.055 & 0.055 & & 0.028 \\
\hline Marital status $\left(\gamma_{20}\right)$ & & $-0.059 * *$ & $-0.059 * *$ & $-0.059 * *$ & $-0.059 * *$ & & -0.022 \\
\hline Age $\left(\gamma_{30}\right)$ & & -0.021 & -0.021 & -0.021 & -0.021 & & $0.063 *$ \\
\hline Occupation $\left(\gamma_{40}\right)$ & & 0.008 & 0.008 & 0.008 & 0.008 & & 0.007 \\
\hline Education $\left(\gamma_{50}\right)$ & & 0.016 & 0.016 & 0.016 & 0.016 & & -0.005 \\
\hline Income $\left(\gamma_{60}\right)$ & & 0.001 & 0.001 & 0.001 & 0.001 & & -0.031 \\
\hline Apology $\left(\gamma_{70}\right)$ & & $0.076 *$ & & & & & \\
\hline Compensation $\left(\gamma_{80}\right)$ & & & $0.221 * * *$ & & & & \\
\hline Speed of response $\left(\gamma_{90}\right)$ & & & & $0.205^{* * *}$ & & & \\
\hline Courtesy $\left(\gamma_{100}\right)$ & & & & & $0.219^{* * *}$ & & \\
\hline Perceived justice $\left(\gamma_{70}\right)$ & & & & & & & $0.925^{* * *}$ \\
\hline Within-team variance $\sigma^{2}$ & & 0.799 & 0.799 & 0.799 & 0.799 & & 0.67 \\
\hline Between-team variance $\tau_{00}$ & & -7.778 & -7.778 & -7.778 & -7.778 & & -32.929 \\
\hline$R^{2}$ & 0.155 & 0.211 & 0.211 & 0.211 & 0.211 & & 1.262 \\
\hline Deviance & 603.962 & 242.109 & 242.109 & 242.109 & 242.109 & & 523.896 \\
\hline
\end{tabular}

\subsubsection{Examination of Moderating Effect}

H5 H8 hypothesize that brand equity moderates the relationship between service recovery and perceived justice. As shown in Table 4., the estimate of the interaction between brand equity and apology was not significant $\left(\gamma_{71}=-0.329, p>0.05\right.$; see M5). The estimate of the interaction between brand equity and speed of response was not significant $\left(\gamma_{71}=-0.157, p>0.05\right.$; see M7).

H6 states that brand equity moderates the relationship between compensation and perceived justice. As expected, the results showed that the interaction between brand equity and compensation was significant $\left(\gamma_{71}=-0.633, p<0.001\right.$; see M6). Thus, H6 was supported. H8 suggests that brand equity moderates the relationship between courtesy and perceived justice. As expected, the results showed that the interaction between brand equity and courtesy was significant $\left(\gamma_{71}=-0.604, p<0.05\right.$; see M8). Thus, $\mathrm{H} 8$ was supported.

$\mathrm{H} 9 \sim \mathrm{H} 12$ hypothesize that brand identity moderates the relationship between service recovery and perceived justice. As shown in Table 5 , the estimate of the interaction between brand identity and apology was not significant $\left(\gamma_{80}=-0.077, p>0.05\right.$; see M9). The estimate of the interaction between brand identity and speed of response was not significant $\left(\gamma_{80}=-0.073, p>0.05\right.$; see M11).

H10 states that brand identity moderates the relationship between compensation and perceived justice. As expected, the results showed that the interaction between brand identity and compensation was significant $\left(\gamma_{80}=-0.125, p<0.05\right.$; see M10). Thus, H10 was supported. H12 suggests that brand identity moderates the relationship between courtesy and perceived justice. As expected, the results showed that the interaction between brand identity and courtesy was significant $\left(\gamma_{80}=-0.245, p<0.001\right.$; see M12). Thus, H12 was supported.

The results of hierarchical linear model analysis and testing of moderating effects are summarized in Table 6. 
Table 4. The HLM results of brand equity, service recovery and perceived justice.

\begin{tabular}{|c|c|c|c|c|c|}
\hline \multirow{2}{*}{ Dependent Variable } & \multicolumn{5}{|c|}{ Perceived Justice } \\
\hline & Null Model & M5 & M6 & M7 & M8 \\
\hline \multicolumn{6}{|l|}{ Individual Level } \\
\hline Intercept $\left(\gamma_{00}\right)$ & $3.752 * * *$ & $3.605^{* * *}$ & $3.605^{* * *}$ & $3.574^{* * *}$ & $3.612 * * *$ \\
\hline Gender $\left(\gamma_{10}\right)$ & & 0.065 & 0.101 & 0.071 & 0.083 \\
\hline Marital status $\left(\gamma_{20}\right)$ & & $-0.069 *$ & $-0.070 * *$ & $-0.069 * *$ & $-0.061^{* *}$ \\
\hline Age $\left(\gamma_{30}\right)$ & & -0.008 & 0.002 & -0.014 & -0.016 \\
\hline Occupation $\left(\gamma_{40}\right)$ & & 0.013 & 0.018 & 0.012 & 0.007 \\
\hline Education $\left(\gamma_{50}\right)$ & & 0.059 & 0.031 & $0.076^{* *}$ & 0.042 \\
\hline Income $\left(\gamma_{60}\right)$ & & 0.022 & -0.014 & -0.027 & -0.010 \\
\hline Apology $\left(\gamma_{70}\right)$ & & $0.382 * * *$ & & & \\
\hline Compensation $\left(\gamma_{70}\right)$ & & & $0.489 * * *$ & & \\
\hline Speed of response $\left(\gamma_{70}\right)$ & & & & $0.485^{* *}$ & \\
\hline Courtesy $\left(\gamma_{70}\right)$ & & & & & $0.447^{* * *}$ \\
\hline \multicolumn{6}{|l|}{ Organizational level } \\
\hline Brand equity $\left(\gamma_{71}\right)$ & & $0.590 * * *$ & $0.064^{* * *}$ & $0.713^{* * *}$ & $0.682^{* * *}$ \\
\hline Brand equity * Apology $\left(\gamma_{71}\right)$ & & -0.329 & & & \\
\hline Brand equity ${ }^{*}$ Compensation $\left(\gamma_{71}\right)$ & & & $-0.633^{* *}$ & & \\
\hline Brand equity $*$ Speed of response $\left(\gamma_{71}\right)$ & & & & -0.157 & \\
\hline Brand equity $*$ Courtesy $\left(\gamma_{71}\right)$ & & & & & -0.604 * \\
\hline Within-team variance $\sigma^{2}$ & & 0.529 & 0.143 & 0.621 & 0.261 \\
\hline Between-team variance $\tau_{00}$ & & -2.935 & -2.104 & -2.845 & -1.05 \\
\hline$R^{2}$ & 0.155 & 0.095 & 0.294 & 0.194 & 0.105 \\
\hline Deviance & 603.962 & 426.390 & 376.681 & 367.982 & 376.681 \\
\hline
\end{tabular}

Notes: $\mathrm{N}=353$ (participants), 32 (online brands) ${ }^{*} p<0.05,{ }^{* *} p<0.01,{ }^{* * *} p<0.001$.

Table 5. The HLM results of brand identity, service recovery and perceived justice.

\begin{tabular}{|c|c|c|c|c|c|}
\hline \multirow{2}{*}{ Dependent Variable } & \multicolumn{5}{|c|}{ Perceived Justice } \\
\hline & Null Model & M9 & M10 & M11 & M12 \\
\hline Individual Level & & & & & \\
\hline Intercept $\left(\gamma_{00}\right)$ & $3.752 * * *$ & $3.605^{* * *}$ & $3.605^{* * *}$ & $3.574^{* * *}$ & $3.612 * * *$ \\
\hline Gender $\left(\gamma_{10}\right)$ & & 0.065 & 0.101 & 0.071 & 0.083 \\
\hline Marital status $\left(\gamma_{20}\right)$ & & $-0.069 *$ & $-0.070^{* *}$ & $-0.069^{* *}$ & $-0.061^{* *}$ \\
\hline Age $\left(\gamma_{30}\right)$ & & -0.008 & 0.002 & -0.014 & -0.016 \\
\hline Occupation $\left(\gamma_{40}\right)$ & & 0.013 & 0.018 & 0.012 & 0.007 \\
\hline Education $\left(\gamma_{50}\right)$ & & 0.059 & 0.031 & $0.076^{* *}$ & 0.042 \\
\hline Income $\left(\gamma_{60}\right)$ & & -0.022 & -0.014 & -0.027 & -0.010 \\
\hline Apology $\left(\gamma_{70}\right)$ & & $0.584 * *$ & & & \\
\hline Compensation $\left(\gamma_{70}\right)$ & & & $0.813^{* * *}$ & & \\
\hline Speed of response $\left(\gamma_{70}\right)$ & & & & $0.542 * *$ & \\
\hline Courtesy $\left(\gamma_{70}\right)$ & & & & & $0.186^{* * *}$ \\
\hline Brand identity & & $0.539 * * *$ & $0.689^{* * *}$ & $0.627^{* * *}$ & $0.231^{* * *}$ \\
\hline Apology ${ }^{*}$ Brand identity $\left(\gamma_{80}\right)$ & & -0.077 & & & \\
\hline Compensation ${ }^{*}$ Brand identity $\left(\gamma_{80}\right)$ & & & $-0.125 *$ & & \\
\hline Speed of response $*$ Brand identity $\left(\gamma_{80}\right)$ & & & & -0.073 & \\
\hline Courtesy $*$ Brand identity $\left(\gamma_{80}\right)$ & & & & & $-0.245^{* * *}$ \\
\hline Within-team variance $\sigma^{2}$ & & 0.651 & 0.225 & 0.717 & 0.285 \\
\hline Between-team variance $\tau_{00}$ & & -10.123 & -0.275 & -14.873 & -0.458 \\
\hline$R^{2}$ & 0.155 & 0.237 & 0.258 & 0.263 & 0.264 \\
\hline Deviance & 603.962 & 371.172 & 319.353 & 319.991 & 303.058 \\
\hline
\end{tabular}

Notes: $\mathrm{N}=353$ (participants), 32 (online brands) ${ }^{*} p<0.05,{ }^{* *} p<0.01{ }^{* * *} p<0.001$. 
Table 6. Results of hypothesis test.

\begin{tabular}{lc}
\hline \multicolumn{1}{c}{ Hypothesis } & Result \\
\hline H1. Apology has a positive effect on perceived justice. & Supported \\
H2. Compensation has a positive effect on perceived justice. & Supported \\
H3. Speed of response has a positive effect on perceived justice. & Supported \\
H4. Courtesy has a positive effect on perceived justice. & Supported \\
H5. Brand equity has a negative moderating effect on the influence of apology on perceived justice. & No Supported \\
H6. Brand equity has a negative moderating effect on the influence of compensation on & Supported \\
perceived justice. & No Supported \\
H7. Brand equity has a negative moderating effect on the influence of speed of response on & Supported \\
perceived justice. & No Supported \\
H8. Brand equity has a negative moderating effect on the influence of courtesy on perceived justice. & Supported \\
H9. Brand identity has a negative moderating effect on the influence of apology on perceived justice. & \\
H10. Brand identity has a negative moderating effect on the influence of compensation on & No Supported \\
perceived justice. & Supported \\
H11. Brand identity has a negative moderating effect on the influence of speed of response on & \\
perceived justice. & Supported \\
p12. Brand identity has a negative moderating effect on the influence of courtesy on & \\
H13. Perceived justice has a positive effect on service recovery satisfaction. &
\end{tabular}

\section{Discussion and Conclusions}

This study explored the influence of various service recovery approaches on customer-perceived justice. Apology, speed of response, compensation, and courtesy were used as typical service recovery approaches to examine the relationships these approaches have with perceived justice. The results showed these service recovery approaches had significant positive effects on the perceived justice of online shoppers (H1, H2, H3, and H4). This finding is consistent with those of several previous studies $[7,47,97]$ and thus verified the conclusions in the previous literature. Therefore, customer-perceived justice is enhanced when online shopping service providers offer appropriate compensation, handle the failures immediately, respond to customer requests instantly, act courteously, and apologize to customers after service failures occur. Simultaneously, customer perception of the service providers is improved. In addition, we investigated the influence of perceived justice on service recovery satisfaction. The results indicated that perceived justice had a positive relationship with service recovery satisfaction (H13). In other words, customers are satisfied with the service recovery a firm makes when the recovery matches customer expectation and customer-perceived justice. This finding is consistent with those of previous studies $[33,51,55,98]$.

Second, few studies have explored whether the relationship between service recovery and perceived justice is moderated. Although a few scholars have used company reputation and brand equity as moderators to examine the relationship between service recovery and service recovery satisfaction [6,99], these moderators both focused on the individual level. Nevertheless, the recent rise in virtual communities has allowed most consumers to formulate purchase decisions by referencing information and experience shared by members of virtual communities. Furthermore, online brands have differing target customers and brand images. Considering the disparity, we employed brand equity as a variable at the organizational level to moderate the influence of service recovery on perceived justice.

When we used brand equity as the moderator, the results showed that brand equity moderated the relationship between compensation and courtesy on perceived justice (H6 and H8), indicating that high brand equity undermines the positive influence of compensation and courtesy on perceived justice. Therefore, we conclude that because compensation is related to the cost-benefit allocation of a firm [100], customers can easily tie compensation to the overall performance of a firm. Customers that do not receive the high compensation they expect are likely to perceive disconfirmation with the brand awareness they hold. Additionally, courtesy, which determines the service management quality of 
service personnel, is a bridge through which customers and firms interact [51]. Customers expect firms with high equity to deliver high-quality service, and consequently, courtesy undermines the influence of high brand equity on compensation and perceived justice.

Third, we hypothesized that brand identity, a factor at the individual level, moderates the relationship between service recovery and perceived justice. No scholars have adopted a similar framework, and we examined the relationships among these factors. The results show that individual customers' brand identity moderates and weakens the influence of compensation and courtesy on perceived justice (H10, H11). Based on this finding, we conclude that customers believe that brands they identify with perceive the customers as unique individuals [31]; therefore, consumers with a strong brand identity have high expectations of firm policies and expect customized service [79]. In addition, compared with brands customers have a weak identity with, customers have significantly higher expectations of the attitude demonstrated by service providers which whom customers highly identify. Therefore, according to the expectancy-disconfirmation theory, consumers with a strong brand identity are likely to feel dissatisfied when they receive compensations and courteous service recovery made by a brand, resulting in the perception of unjust experience [12]. Brand equity, a factor at the organizational level, represents aggregated customer perception of a brand and externalized value. However, brand identity is a unique perception people have of a brand, indicating that a customer recognizes the brand as a unique existence. By contrast, customers consider apology and speed of response and indication of the performance and personal quality of service personnel; therefore, these two factors do not affect overall customer perception of the brand. Hence, brand identity does not moderate the influence of apology and speed of response on perceived justice.

Fourth, the results of this study show that brand equity and brand identity have no significant moderating effect on the influence of apology and speed of response on perceived justice (H5 and H7) (H9 and H11). Statistical results relating to the two factors were similar. Previous studies have argued that customer brand identity is correlated with brand equity [101,102]. Therefore, we conclude that apology can be viewed as a form of psychological compensation, which reflects the empathy a firm shows toward customer complaints [103]. However, because of the sophisticated orders, product complexity, and customer alienation in an online environment [2], service providers might act without empathy when filling a massive amount of orders for customers they have no physical contact with. Therefore, we conclude online shoppers might have a higher failure tolerance of products and service provided in this context and they do not associate the failure with brand performance.

Fifth, the speed of response is the flexibility and speed with which service personnel respond to customers. Because online retailers employ a large force of customer service personnel, customers might be served by differing service providers when communicating their problems to customer service. The service provided by various people changes over time and space; therefore, customers consider service efficiency a result of the emotional act and instant performance of service providers. In particular, customers with a strong brand identity perceive a unique connection between themselves and the brand. Hence, the personal behavior and performance of individual service providers do not change customer perception of brand image, and customers do not associate individual staff behavior with the brand.

Based on the law of diminishing marginal utility, the effects of sincere apology and speedy responses are significant when customers receive the first response. However, customers are less impressed and perceive no difference after the service recovery made by a firm reaches a high level or when the customer receives frequent apologies from service personnel. According to this law, customers would transfer the limited resources they have to satisfy other desires after customers have received a certain amount of product service. Therefore, to achieve satisfaction, customers transfer their attention to the compensation measures a firm adopts. In this situation, differentiated service attitude and compensation can have significant influence on customer perception. Furthermore, marginal utility is unlikely to decline; therefore, customers with a strong brand identity tend to have high 
expectations of service personnel performance and the anticipated compensation provided by firms with high equity.

\subsection{Theoretical Implication}

This study has several implications and makes a number of contributions. The findings of this study are described as follows: (a) The study based on the online service recovery methods proposed by Mostafa (2014) [58], we investigated the effects of various types of recovery methods on customer-perceived justice and on subsequent service recovery satisfaction; (b) we explored whether the brand equity of business organizations has a moderating effect on the relationship between business service recovery and customer-perceived justice; and (c) we examined whether the brand identity of individual customers has a moderating effect on the relationship between business service recovery and customer-perceived justice. (d) Regarding the methodology of this study, previous studies on service recovery primarily adopted linear structural equation models. By contrast, this study adopted HLM as the research framework because brand perception differs at various levels and adopting HLM allows us to precisely understand the influence of brand identity and brand equity on the relationship between service recovery and perceived justice. This method enhances the explanatory power of the results. These findings are vital developments and contributions we make to the field of e-commerce brand marketing.

\subsection{Managerial and Practical Implications}

With the prevalence of the Internet and mobile devices, competition among online shopping sites is increasingly fierce. Brand management is a vital issue for improving company competitiveness [21]. First, the results of this study show that high brand equity can undermine the positive influence of service recovery on customer-perceived justice. In other words, when service failure occurs in firms with high brand equity, customers are sensitive to the inadequacy in service recovery and are therefore dissatisfied with the service. Simultaneously, customer satisfaction increases when firms with high brand equity adopt efficient service recovery measures. These results indicate that service providers must respond to customers immediately and provide and create valuable products and services that match brand equity if firm managers intend to establish and maintain high brand equity [6]). In this study, the hypotheses regarding how brand equity moderates the influence of apology and speed of response were rejected. This is possibly because the study was conducted on the subject of online shopping, where customer evaluation of speed of response and apology might be separated from overall brand evaluation. Therefore, in addition to improving service personnel management and firm policy communication, firm managers should improve the response efficiency, spontaneity, and active attitude in service recovery, particularly in an environment featuring massive and complex transactions such as the Internet. In other words, service providers should enhance convenience, which is a discerning feature of online shopping.

Furthermore, the results of this study show that a strong brand identity can undermine the positive influence of service recovery on customer-perceived justice. Specifically, when service failure occurs in firms a customer has a strong identification and commitment with, the customer is likely to heed the inadequacy of service recovery and feel dissatisfied with the service. Based on this finding, we have the following recommendations: first, to serve customers with a strong brand identity, firm management should formulate flexible policies, ensure service providers receive sufficient training, and encourage a friendly service attitude. Furthermore, customers with a strong identity consider themselves unique to the brand [32]. Therefore, we recommend that online shopping brands set up a Very Important Person (VIP) system, providing customized service and highly flexible compensation mechanisms for customers with a strong brand identity. In the age of big data and information, firms holding a large amount of customer information have greater competitive advantages.

Second, we found brand equity and brand identity had no effect on the influence of apology and speed of response on recovery perception. Apology and speed of response, as two recovery strategies, 
hardly differ between various brands. According to the law of diminishing marginal utility, when firms apologize and actively respond to customer concerns, these actions result in minor differences in customer perception after the recovery measures exceed a high standard. Therefore, we recommend that firms invest their resources in courtesy and compensation, two types of recovery that can result in significant difference in customer perception. To achieve this goal, we recommend online shopping brands set up a customer management system and formulate a well-defined and customized courteous procedure for front-line service personnel to follow when encountering complaints filed by customers with a strong brand identity. In addition, service providers should offer compensations (in the form of coupons or gifts) to ensure the experience exceeds the expectation of customers with a strong brand identity.

\subsection{Limitations and Future Research}

The following suggestions are proposed as a reference for future studies. First, online shopping as an emerging industry is popular among young users, considering that technology products are necessary for making purchases. Therefore, obtaining middle-aged and elderly samples is difficult. Consequently, we are unable to precisely analyze and explore overall social perception of online brands and the future significance of online shopping. Hence, we recommend future scholars focus on the middle-aged and elderly population to comprehensively investigate the interaction between online brands and service recovery.

Second, we focused on the influence of online brand equity and customer brand perception on customer perception of service recovery. Nevertheless, in addition to brands, the recent rise in online social communities should not be overlooked [104]. These communities have significant influence on firms and individuals. Therefore, we recommend future scholars use the connotation of social community as a moderator to further examine the influence of online communities on service recovery.

Author Contributions: T.-E.L. proposed the conceptualization and wrote the manuscripts. Y.-H.L. conducted literature review and performed data analysis. J.-W.H. helped data collection. All authors have read and agreed to the published version of the manuscript.

Funding: This research received no external funding.

Conflicts of Interest: The authors declare no conflict of interest.

\section{Appendix A}

Table A1. Measurements of constructs.

\begin{tabular}{l} 
Constructs/Sources/Items \\
$\begin{array}{l}\text { Service Recovery } \\
\text { Apology: }\end{array}$ \\
\hline The company apologized to me for what had happened \\
The company expressed regret for the mistake that occurred \\
The company apologized for the inconvenience the problem had brought to me \\
The company apologized for what I have suffered because of the problem \\
Compensation: \\
The compensation the company gave me for the loss incurred is good \\
The compensation the company gave me for all the time I spent dealing with the complaint is good \\
The compensation the company provided me to cover my financial losses is good \\
The compensation the company gave me for all the hard times I had due to the complaint is good \\
The compensation the company provided me for the inconvenience I went through due to the complaint \\
is good
\end{tabular}


Table A1. Cont.

\begin{tabular}{|c|c|}
\hline \multicolumn{2}{|c|}{ Constructs/Sources/Items } \\
\hline \multicolumn{2}{|c|}{ Service Recovery } \\
\hline Speed of response: & Reference: Mostafa et al.(2014) \\
\hline \multicolumn{2}{|c|}{$\begin{array}{l}\text { The company reacted promptly to my inquiries } \\
\text { The company attended to the problem quickly } \\
\text { The company responded to my complaint promptly } \\
\text { Solving the problem did not take so long }\end{array}$} \\
\hline Courtesy: & Reference: Mostafa et al.(2014) \\
\hline \multicolumn{2}{|c|}{$\begin{array}{l}\text { The service provider was friendly to me } \\
\text { The service provider was polite to me } \\
\text { The service provider showed respect to me } \\
\text { The service provider was patient with me }\end{array}$} \\
\hline \multicolumn{2}{|c|}{ Perceived Justice } \\
\hline Distributive Justice: & Reference: del Río-Lanza et al. (2009) \\
\hline $\begin{array}{l}\text { Considering the trouble caused } \\
\text { was acceptable } \\
\text { This shopping websites efforts } \\
\text { I think this shopping website } \mathrm{w} \\
\text { In general, this shopping websi } \\
\text { delivery of the service }\end{array}$ & $\begin{array}{l}\text { mpensation I received from this shopping website } \\
\text { satisfactory compensation } \\
\text { ensating me for the problem that occurred } \\
\text { te me adequately to solve the problems it had in the }\end{array}$ \\
\hline Procedural Justice: & Reference: del Río-Lanza et al. (2009) \\
\hline $\begin{array}{l}\text { I think my problem was resolve } \\
\text { I think this shopping website } h \\
\text { Despite the trouble caused by } t \\
\text { This shopping website proved } \\
\text { This shopping website tried to }\end{array}$ & $\begin{array}{l}\text { actices for dealing with problems } \\
\text { ing website was able to respond adequately } \\
\text { roblem } \\
\text { uickly as possible }\end{array}$ \\
\hline Interactional Justice: & Reference: del Río-Lanza et al. (2009) \\
\hline $\begin{array}{l}\text { The employees in this shopping } \\
\text { The employees in this shopping } \\
\text { The employees in this shopping } \\
\text { The employees in this shopping } \\
\text { The employees in this shopping } \\
\text { The employees in this shopping } \\
\text { The treatment and communicat } \\
\text { were acceptable }\end{array}$ & $\begin{array}{l}\text { st in my problem } \\
\text { possible to solve my problem } \\
\text { hen dealing with my problem } \\
\text { d to have enough authority to solve the problem } \\
\text { courteously when solving the problem } \\
\text { st in being fair when solving the problem } \\
\text { his shopping website to solve the problem }\end{array}$ \\
\hline Service Recovery Satisfaction & Reference: Smith et al. (1999) \\
\hline $\begin{array}{l}\text { Overall I was satisfied with the } \\
\text { Overall I got what I wanted } \\
\text { They really tried to help }\end{array}$ & handled \\
\hline
\end{tabular}

\begin{tabular}{lc}
\hline & Brand Equity \\
\hline Perceived Quality: & Reference: Pappu et al. (2005) \\
\hline
\end{tabular}

$X$ offers good quality services

$X$ offers very reliable services

Quality of services provided by $\mathrm{X}$ are consistent

The likely quality of $X$ is extremely high

\begin{tabular}{l}
\hline Brand Association: \\
\hline I trust the company that owns the brand X \\
I like the company which owns X \\
The company that markets $(X)$ really cares about its customers \\
$X$ is a honest brand \\
$X$ offers value for money services
\end{tabular}


Table A1. Cont.

\begin{tabular}{|c|c|}
\hline \multicolumn{2}{|c|}{ Constructs/Sources/Items } \\
\hline \multicolumn{2}{|c|}{ Brand Equity } \\
\hline Brand Image: & Reference: Netemeyer et al. (2004) \\
\hline $\begin{array}{l}\mathrm{X} \text { has a clean image } \\
\mathrm{X} \text { has a strong image } \\
\text { Overtime, } \mathrm{X} \text { has been very consisten } \\
\mathrm{X} \text { is familiar to me }\end{array}$ & inds for \\
\hline Brand Identity: & Reference: Bhattacharya \& Sankar (2003) \\
\hline $\begin{array}{l}\mathrm{X} \text { has a distinctive identity } \\
\mathrm{X} \text { stands out from its competitors } \\
\mathrm{X} \text { is a first-class, high-quality brand } \\
\mathrm{X} \text { has a high reputation }\end{array}$ & \\
\hline
\end{tabular}

Note: The measurement was based on a Likert5-point scale, ranging from 1 (strongly disagree) to 5 (strongly agree).

\section{References}

1. Fisk, R.P.; Brown, S.W.; Bitner, M.J. Tracking the evolution of the services marketing literature. J. Retail. 1993, 69, 61-103. [CrossRef]

2. Holloway, B.B.; Beatty, S.E. Service Failure in Online Retailing: A Recovery Opportunity. J. Serv. Res. 2003, 6, 92-105. [CrossRef]

3. Akinci, S.; Atilgan-Inan, E.; Aksoy, S. Re-assessment of ES-Qual and E-RecS-Qual in a pure service setting. J. Bus. Res. 2010, 63, 232-240. [CrossRef]

4. McColl-Kennedy, J.R.; Sparks, B.A. Application of Fairness Theory to Service Failures and Service Recovery. J. Serv. Res. 2003, 5, 251-266. [CrossRef]

5. Rowley, J. Online branding. Online Inf. Rev. 2004, 28, 131-138. [CrossRef]

6. Huang, M.-H. Re-examining the effect of service recovery: The moderating role of brand equity. J. Serv. Mark. 2011, 25, 509-516. [CrossRef]

7. Del Río-Lanza, A.B.; Casielles, R.V.; Díaz-Martín, A.M. Satisfaction with service recovery: Perceived justice and emotional responses. J. Bus. Res. 2009, 62, 775-781. [CrossRef]

8. Hocutt, M.A.; Bowers, M.R.; Donavan, D.T. The art of service recovery: Fact or fiction? J. Serv. Mark. 2006, 20, 199-207. [CrossRef]

9. Maxham, J.G.; Netemeyer, R.G. Firms Reap what they Sow: The Effects of Shared Values and Perceived Organizational Justice on Customers' Evaluations of Complaint Handling. J. Mark. 2003, 67, 46-62. [CrossRef]

10. Mattila, A.S.; Patterson, P.G. Service Recovery and Fairness Perceptions in Collectivist and Individualist Contexts. J. Serv. Res. 2004, 6, 336-346. [CrossRef]

11. Wu, L.-Y.; Chen, K.-Y.; Chen, P.-Y.; Cheng, S.-L. Perceived value, transaction cost, and repurchase-intention in online shopping: A relational exchange perspective. J. Bus. Res. 2014, 67, 2768-2776. [CrossRef]

12. Oliver, R.L. Satisfaction: A Behavioral Perspective on the Consumer; M.E. Sharpe: Armonk, NY, USA, 2010.

13. Kotler, P. Marketing Management, 7th ed.; Prentice-Hall, Inc.: Englewood Cliffs, NJ, USA, 1991.

14. Barwise, P. Brand equity: Snark or boojum? Int. J. Res. Mark. 1993, 10, 93-104. [CrossRef]

15. Baalbaki, S.; Guzmán, F.; Baalbaki, F.G.S. A consumer-perceived consumer-based brand equity scale. J. Brand Manag. 2016, 23, 229-251. [CrossRef]

16. Christodoulides, G.; De Chernatony, L. Dimensionalising on- and offline brands' composite equity. J. Prod. Brand Manag. 2004, 13, 168-179. [CrossRef]

17. Kim, J.; Sharma, S.; Setzekorn, K. A framework for building brand equity online for pure-play B2C retailers and services. Int. J. Media Manag. 2002, 4, 123-133. [CrossRef]

18. Laudon, K.C.; Traver, C.G.; Elizondo, A.V.R. E-Commerce; Addison-Wesley: Boston, MA, USA, 2007.

19. Aaker, D.A. Managing Brand Equity; The Free Press: New York, NY, USA, 1991.

20. Keller, K.L.; Parameswaran, M.; Jacob, I. Strategic Brand Management: Building, Measuring, and Managing Brand Equity; Pearson Education India: Noida, India, 2011.

21. Aaker, D.A. Building Strong Brands; Simon and Schuster: New York, NY, USA, 2012. 
22. Ambler, T.; Bhattacharya, C.B.; Edell, J.; Keller, K.L.; Lemon, K.N.; Mittal, V. Relating Brandand Customer Perspectives on Marketing Management. J. Serv. Res. 2002, 5, 13-25. [CrossRef]

23. De Chernatony, L.; Drury, S.; Segal-Horn, S. Building a Services Brand: Stages, People and Orientations. Serv. Ind. J. 2003, 23, 1-21. [CrossRef]

24. Zeithaml, V.A. Consumer Perceptions of Price, Quality, and Value: A Means-End Model and Synthesis of Evidence. J. Mark. 1988, 52, 2-22. [CrossRef]

25. Yoo, B.; Donthu, N. Developing and validating a multidimensional consumer-based brand equity scale. J. Bus. Res. 2001, 52,1-14. [CrossRef]

26. Berry, L.L. Cultivating Service Brand Equity. J. Acad. Mark. Sci. 2000, 28, 128-137. [CrossRef]

27. Kim, H.-B.; Kim, W.G. The relationship between brand equity and firms' performance in luxury hotels and chain restaurants. Tour. Manag. 2005, 26, 549-560. [CrossRef]

28. Prasad, K.; Dev, C.S. Managing Hotel Brand Equity: A customer-centric framework for assessing performance. Cornell Hotel. Restaur. Adm. Q. 2000, 41, 22-31. [CrossRef]

29. Belk, R. Possessions and Self; Wiley Online Library: Hoboken, NJ, USA, 1988.

30. Ghodeswar, B.M. Building brand identity in competitive markets: A conceptual model. J. Prod. Brand Manag. 2008, 17, 4-12. [CrossRef]

31. Lam, S.K.; Ahearne, M.; Hu, Y.; Schillewaert, N. Resistance to Brand Switching when a Radically New Brand is Introduced: A Social Identity Theory Perspective. J. Mark. 2010, 74, 128-146. [CrossRef]

32. McEwen, W.J. Married to the Brand: Why Consumers Bond. With Some Brands for Life; Simon and Schuster: New York, NY, USA, 2005.

33. Smith, A.K.; Bolton, R.N.; Wagner, J. A model of customer satisfaction with service encounters involving failure and recovery. J. Mark. Res. 1999, 36, 356-372. [CrossRef]

34. Sun, H.; He, D. "Refunds" or "Discounts"? Exploring the Compensation Framing Effect on Consumer's Perceived Fairness of Online Service Recovery. In Proceedings of the WHICEB 2014, Wuhan, China, 31 May-1 June 2014; p. 90.

35. Wang, Y.-S.; Wu, S.-C.; Lin, H.-H.; Wang, Y.-Y. The relationship of service failure severity, service recovery justice and perceived switching costs with customer loyalty in the context of e-tailing. Int. J. Inf. Manag. 2011, 31, 350-359. [CrossRef]

36. Raudenbush, S.W.; Bryk, A.S. Hierarchical Linear Models: Applications and Data Analysis Methods, 2nd ed.; Sage: Thousand Oaks, CA, USA, 2002.

37. Maxham, J.G., III. Service recovery's influence on consumer satisfaction, positive word-of-mouth, and purchase intentions. J. Bus. Res. 2001, 54, 11-24. [CrossRef]

38. Keaveney, S.M. Customer Switching Behavior in Service Industries: An Exploratory Study. J. Mark. 1995, 59, 71-82. [CrossRef]

39. Barwise, P.; Elberse, A.; Hammond, K. Marketing and the Internet: A Research Review; London Business School: London, UK, 2002.

40. Kuo, Y.-F.; Yen, S.-T.; Chen, L.-H. Online auction service failures in Taiwan: Typologies and recovery strategies. Electron. Commer. Res. Appl. 2011, 10, 183-193. [CrossRef]

41. Baron, S.; Harris, K.; Elliott, D.; Forbes, L.P.; Kelley, S.W.; Hoffman, K.D. Typologies of e-commerce retail failures and recovery strategies. J. Serv. Mark. 2005, 19, 280-292. [CrossRef]

42. Grönroos, C. New Competition in the Service Economy: The Five Rules of Service. Int. J. Oper. Prod. Manag. 1988, 8, 9-19. [CrossRef]

43. Bitner, M.J. Evaluating service encounters: The effects of physical surroundings and employee responses. J. Mark. 1990, 54, 69-82. [CrossRef]

44. Harris, K.E.; Grewal, D.; Mohr, L.A.; Bernhardt, K.L. Consumer responses to service recovery strategies: The moderating role of online versus offline environment. J. Bus. Res. 2006, 59, 425-431. [CrossRef]

45. Hoffman, K.D.; Kelley, S.W.; Chung, B.C. A CIT investigation of servicescape failures and associated recovery strategies. J. Serv. Mark. 2003, 17, 322-340. [CrossRef]

46. Holloway, B.B.; Beatty, S.E. Satisfiers and Dissatisfiers in the Online Environment: A critical incident assessment. J. Serv. Res. 2008, 10, 347-364. [CrossRef]

47. Kuo, Y.-F.; Wu, C.-M. Satisfaction and post-purchase intentions with service recovery of online shopping websites: Perspectives on perceived justice and emotions. Int. J. Inf. Manag. 2012, 32, 127-138. [CrossRef]

48. Homans, G.C. The Humanities and the Social Sciences. Am. Behav. Sci. 1961, 4, 3-6. [CrossRef] 
49. Konovsky, M.A. Understanding procedural justice and its impact on business organizations. J. Manag. 2000, 26, 489-511. [CrossRef]

50. Shapiro, T.; Nieman-Gonder, J. Effect of communication mode in justice-based service recovery. Manag. Serv. Qual. Int. J. 2006, 16, 124-144. [CrossRef]

51. Chebat, J.-C.; Slusarczyk, W. How emotions mediate the effects of perceived justice on loyalty in service recovery situations: An empirical study. J. Bus. Res. 2005, 58, 664-673. [CrossRef]

52. Collier, J.E.; Bienstock, C.C. Measuring Service Quality in E-Retailing. J. Serv. Res. 2006, 8, 260-275. [CrossRef]

53. Schoefer, $\mathrm{K}$. The role of cognition and affect in the formation of customer satisfaction judgements concerning service recovery encounters. J. Consum. Behav. 2008, 7, 210-221. [CrossRef]

54. Goodwin, C.; Ross, I. Salient dimensions of perceived fairness in resolution of service complaints. J. Consum. Satisf. Dissatisfaction Complain. Behav. 1989, 2, 87-92.

55. Tax, S.S.; Brown, S.W.; Chandrashekaran, M. Customer evaluations of service complaint experiences: Implications for relationship marketing. J. Mark. 1998, 62, 60-76. [CrossRef]

56. Blodgett, J.G.; Hill, D.J.; Tax, S.S. The effects of distributive, procedural, and interactional justice on postcomplaint behavior. J. Retail. 1997, 73, 185-210. [CrossRef]

57. Clemmer, E.C.; Schneider, B. Managing customer dissatisfaction with waiting: Applying social-psychological theory in a service setting. Adv. Serv. Mark. Manag. 1993, 2, 213-229.

58. Mostafa, R.; Lages, C.R.; Sääksjärvi, M. The CURE scale: A multidimensional measure of service recovery strategy. J. Serv. Mark. 2014, 28, 300-310. [CrossRef]

59. Miller, J.L.; Craighead, C.W.; Karwan, K.R. Service recovery: A framework and empirical investigation. J. Oper. Manag. 2000, 18, 387-400. [CrossRef]

60. Varela, J.C.S.; Svensson, G.; Brambilla, F.R.; Oliveros, M.E.G. Perceived Justice \& Emotions in a Negative Service Encounter: A Latin American Perspective. In Ideas in Marketing: Finding the New and Polishing the Old; Springer Science and Business Media LLC: Berlin, Gremany, 2014; pp. 413-416.

61. Oliver, R.L. A cognitive model of the antecedents and consequences of satisfaction decisions. J. Mark. Res. 1980, 17, 460-469. [CrossRef]

62. Oliver, R.L.; Desarbo, W.S. Response Determinants in Satisfaction Judgments. J. Consum. Res. 1988, 14, 495. [CrossRef]

63. James, K.; Babin, B.J.; Borges, A. Retailer Success: Value and Satisfaction Ideas in Marketing: Finding the New and Polishing the Old; Springer: New York, NY, USA, 2015; pp. 436-438.

64. Sarkar, A.; Krishnan, B.C.; Balaji, M.S. Brand Reputation: Does It Help Customers Cope with Service Failure? Ideas in Marketing: Finding the New and Polishing the Old; Springer: New York, NY, USA, 2015; pp. 693-696.

65. Parasuraman, A.; Zeithaml, V.A.; Berry, L.L. A Conceptual Model of Service Quality and Its Implications for Future Research. J. Mark. 1985, 49, 41-50. [CrossRef]

66. Aaker, D.A. Managing Brand Equity; Simon and Schuster: New York, NY, USA, 2009.

67. Kapferer, J.-N. The New Strategic Brand Management: Advanced Insights and Strategic Thinking; Kogan Page: London, UK, 2012.

68. Merrilees, B.; Fry, M.-L. Corporate Branding: A Framework for E-retailers. Corp. Reput. Rev. 2002, 5, $213-225$. [CrossRef]

69. Klaus, P.; Maklan, S. Towards a Better Measure of Customer Experience. Int. J. Mark. Res. 2013, 55, $227-246$. [CrossRef]

70. Andreassen, T.W. Antecedents to satisfaction with service recovery. Eur. J. Mark. 2000, 34, 156-175. [CrossRef]

71. Brady, M.K.; Croninjr, J.; Fox, G.; Roehm, M.L. Strategies to offset performance failures: The role of brand equity. J. Retail. 2008, 84, 151-164. [CrossRef]

72. Oliver, R.L. Satisfaction: A Behavioral Perspective on the Consumer; Irwin-McGraw-Hill: New York, NY, USA, 1997.

73. Hess, R.L. The impact of firm reputation and failure severity on customers' responses to service failures. J. Serv. Mark. 2008, 22, 385-398. [CrossRef]

74. Camarero, C.; Garrido, M.J.; Vicente, E. Components of art exhibition brand equity for internal and external visitors. Tour. Manag. 2010, 31, 495-504. [CrossRef]

75. Balmer, J.M.; van Riel, C.B.; van Riel, C.B.; Balmer, J.M. Corporate identity: The concept, its measurement and management. Eur. J. Mark. 1997, 31, 340-355. 
76. Stuart, H. Employee Identification with the Corporate Identity-Issues and Implications. Int. Stud. Manag. Organ. 2002, 32, 28-44. [CrossRef]

77. Desai, K.K.; Raju, S. Adverse influence of brand commitment on consideration of and preference for competing brands. Psychol. Mark. 2007, 24, 595-614. [CrossRef]

78. Holbrook, M.B. The Nature of Customer Value: An Axiology of Services in the Consumption Experience. Serv. Qual. New Dir. Theory Pract. 2012, 21, 21-71. [CrossRef]

79. Varela-Neira, C.; Vázquez-Casielles, R.; Iglesias, V. The effects of customer age and recovery strategies in a service failure setting. J. Financial Serv. Mark. 2010, 15, 32-48. [CrossRef]

80. Orsingher, C.; Valentini, S.; De Angelis, M. A meta-analysis of satisfaction with complaint handling in services. J. Acad. Mark. Sci. 2009, 38, 169-186. [CrossRef]

81. Huang, W. The impact of other-customer failure on service satisfaction. Int. J. Serv. Ind. Manag. 2008, 19, 521-536. [CrossRef]

82. Pappu, R.; Quester, P.G.; Cooksey, R.W. Consumer-based brand equity: Improving the measurement-Empirical evidence. J. Prod. Brand Manag. 2005, 14, 143-154. [CrossRef]

83. Netemeyer, R.G.; Krishnan, B.; Pullig, C.; Wang, G.; Yagci, M.; Dean, D.; Ricks, J.; Wirth, F. Developing and validating measures of facets of customer-based brand equity. J. Bus. Res. 2004, 57, 209-224. [CrossRef]

84. Bhattacharya, C.B.; Sen, S. Consumer-Company Identification: A Framework for Understanding Consumers' Relationships with Companies. J. Mark. 2003, 67, 76-88. [CrossRef]

85. Lau, G.T.; Lee, S.H. Consumers' Trust in a Brand and the Link to Brand Loyalty. J. Mark. Manag. 1999, 4, 341-370. [CrossRef]

86. Podsakoff, P.M.; MacKenzie, S.B.; Lee, J.Y.; Podsakoff, N.P. Common Method Biases in Behavioral Research: A Critical Review of the Literature and Recommended Remedies. J. Appl. Psychol. 2003, 88, 879-903. [CrossRef] [PubMed]

87. Podsakoff, P.M.; Organ, D.W. Self-Reports in Organizational Research: Problems and Prospects. J. Manag. 1986, 12, 531-544. [CrossRef]

88. Hair, J.F.; Anderson, R.E.; Tatham, R.L.; Black, W.C. Multivariate Data Analysis; Prentice Hall International: Upper Saddle River, NJ, USA, 1998.

89. Jiang, J.J.; Klein, G.; Carr, C.L. Measuring Information System Service Quality: SERVQUAL from the Other Side. MIS Q. 2002, 26, 145. [CrossRef]

90. Hair, J.F.; Anderson, R.E.; Tatham, R.L.; Black, W.C. Multivariate Data Analysis; Prentice Hall International: Upper Saddle River, NJ, USA, 2009.

91. Fornell, C.; Larcker, D.F. Evaluating structural equation models with unobservable variables and measurement error. J. Mark. Res. 1981, 18, 39-50. [CrossRef]

92. James, L.R.; Demaree, R.G.; Wolf, G. Estimating within-group interrater reliability with and without response bias. J. Appl. Psychol. 1984, 69, 85-98. [CrossRef]

93. Muthén, B.O. Multilevel Covariance Structure Analysis. Sociol. Methods Res. 1994, 22, 376-398. [CrossRef]

94. Glick, W.H. Conceptualizing and measuring organizational and psychological climate: Pitfalls in multilevel research. Acad. Manag. Rev. 1985, 10, 601-616. [CrossRef]

95. Chen, G.; Bliese, P.D. The role of different levels of leadership in predicting self-and collective efficacy: Evidence for discontinuity. J. Appl. Psychol. 2002, 87, 549-556. [CrossRef]

96. Lebreton, J.M.; Senter, J.L. Answers to 20 Questions about Interrater Reliability and Interrater Agreement. Organ. Res. Methods 2007, 11, 815-852. [CrossRef]

97. Chang, C.C. Choice, perceived control, and customer satisfaction: The psychology of online service recovery. Cyberpsychol Behav. 2008, 11, 321-328. [CrossRef]

98. Ha, J.; Jang, S. Perceived justice in service recovery and behavioral intentions: The role of relationship quality. Int. J. Hosp. Manag. 2009, 28, 319-327. [CrossRef]

99. Kuo, Y.-F.; Wu, C.-M.; Yang, S.-C.; Yen, S.-T. Relationships among online shopping service failure types, service recovery strategies, perceived justice, and satisfaction with service recovery. J. e-Bus. 2014, 16, 53-84.

100. Karatepe, O.M. Customer complaints and organizational responses: The effects of complainants' perceptions of justice on satisfaction and loyalty. Int. J. Hosp. Manag. 2006, 25, 69-90. [CrossRef]

101. Keller, K.L. Building customer-based brand equity. Mark. Manag. 2001, 10, 14-21. 
102. Madhavaram, S.; Badrinarayanan, V.A.; McDonald, R.E. Integrated marketing communication (IMC) and brand identity as critical components of brand equity strategy: A conceptual framework and research propositions. J. Advert. 2005, 34, 69-80. [CrossRef]

103. Davidow, M. The Bottom Line Impact of Organizational Responses to Customer Complaints. J. Hosp. Tour. Res. 2000, 24, 473-490. [CrossRef]

104. Lee, M.R.; Yen, D.C.; Hsiao, C. Understanding the perceived community value of Facebook users. Comput. Hum. Behav. 2014, 35, 350-358. [CrossRef]

(C) 2020 by the authors. Licensee MDPI, Basel, Switzerland. This article is an open access article distributed under the terms and conditions of the Creative Commons Attribution (CC BY) license (http://creativecommons.org/licenses/by/4.0/). 